\title{
Respon dan Keberdayaan Petani dalam Program Corporate Social Responsibility PT Pertamina di D.I. Yogyakarta
}

\section{Response and Empowerment of Farmers in PT Pertamina's Corporate Social Responsibility Program at D.I. Yogyakarta}

\author{
Oleh: \\ Christine Sri Widiputranti \\ Sekolah Tinggi Pembangunan Masyarakat Desa “APMD” Yogyakarta \\ "email: christinewidiputranti@gmail.com
}

Received March 15, 2020; Revised July 05, 2020; Accepted August 11, 2020

\begin{abstract}
ABSTRAK
Corporate Social Responsibility (CSR) merupakan etika bisnis perusahaan yang diimplementasikan dalam suatu program untuk meningkatkan sosial ekonomi masyarakat sekitar perusahaan. Dalam penelitian ini, PT Pertamina Terminal Bahan Bakar Minyak Rewulu melaksanakan kegiatan CSR guna meningkatkan keberdayaan masyarakat. Penelitian bertujuan untuk mengetahui hubungan/ pengaruh antara aktivitas program CSR dengan respons petani, dan respons dengan keberdayaan petani. Penelitian dilaksanakan di Desa Argomulyo Kecamatan Sedayu Kabupaten Bantul yang merupakan area sekitar perusahaan Pertamina. Penelitian dilakukan dengan metode survey, dengan mengambil sampel sejumlah 22 orang petani dengan teknik Simple Random Sampling. Analisis dilakukan secara deskriptif dan statistik non parametrik (korelasi spearman) untuk melihat hubungan antara respons petani tarhadap program CSR dengan keberdayaan petani. Hasil penelitian menunjukkan bahwa ada korelasi positif antara aktivitas program CSR dengan respon petani, juga korelasi positif antara respon petani dengan tingkat keberdayaan. Semakin tinggi aktivitas program pertanian organik maka akan meningkatkan respon petani dalam bertani organik. CSR dinilai meningkatkan semangat kerja yang menyebabkan peningkatkan keberdayaan petani, yakni mampu meningkatkan pengetahuan, keterampilan, mengatasi problema cara berproduksi, pengolahan, dan pengembangan usaha.
\end{abstract}

Kata kunci: Corporate Social Responsibility, respons, keberdayaan, petani

\section{ABSTRACT}

Corporate Social Responsibility (CSR) is a company's business ethics that is implemented in a program to improve the socio-economic conditions of the community around the company. In this study, PT Pertamina Rewulu Oil Fuel Terminal carried out CSR activities to increase community empowerment. This study aims to determine the relationship / influence between CSR program activities and farmer responses, and responses to farmer empowerment. The research was conducted in Argomulyo Village, Sedayu District, Bantul Regency, which is the area around the Pertamina company. The research was conducted using a survey method, by taking a sample of 22 farmers using the simple random sampling technique. The analysis was carried out descriptively and non-parametric statistics (spearman correlation) to see the relationship between farmers' responses to the CSR program and farmer empowerment. The results showed that there was a positive correlation between CSR program activities and farmer responses, as well as a positive correlation between farmer responses and the level of empowerment. The higher the activity of the organic farming program will increase the response of farmers in organic farming. CSR is considered to increase morale which leads to increased farmer empowerment, namely being able to increase knowledge, skills, overcoming problems with production, processing and business development.

Keywords: Corporate Social Responsibility, response, empowerment, farmers 


\section{PENDAHULUAN}

Ada berbagai cara pemberdayaan, diantaranya melalui pembinaan, penyuluhan, sehingga individu yang diberi penyuluhan ataupun dibina menjadi meningkat pengetahuan dan keterampilannya, serta berubah sikapnya dan mampu mengatasi problema yang dihadapi. Menurut Widiputranti (2007), pemberdayaan petani adalah upaya agar petani menjadi berdaya yakni mempunyai kemampuan, akal, untuk mengatasi persoalan usaha yang dihadapi (Yanfika et al. 2020). Ada berbagai pengertian petani. Petani adalah setiap orang yang melakukan usaha untuk memenuhi sebagian atau seluruh kebutuhan kehidupannya di bidang pertanian dalam arti luas yang meliputi usaha tani pertanian, peternakan, perikanan (termasuk penangkapan ikan) dan mengutamakan hasil laut (Hasanuddin, Viantimala, Fitriyanai, 2019). Menurut Mosher (1984) petani adalah manusia yang mengendalikan tanaman dan hewan. Dalam menjalankan usahataninya, tiap petani memegang peranan sebagai jurutani (cultivator) sekaligus seorang pengelola (manager). Apabila keterampilan bercocok tanam sebagai juru tani pada umumnya adalah keterampilan tangan, otot dan mata, maka keterampilan sebagai pengelola mencakup kegiatan pikiran didorong oleh kemauan. Tercakup di dalamnya terutama pengambilan keputusan atau penetapan pilihan dari alternatifalternatif yang ada. Dalam Undang Undang Nomor 16 Tahun 2006 tentang Sistem Penyuluhan Pertanian, Perikanan dan Kehutanan, pengertian petani adalah perorangan warga negara Indonesia beserta keluarganya atau koperasi yang mengelola usaha di bidang pertanian, wanatani, minatani, agropasture, penangkaran satwa dan tumbuhan, di dalam dan di sekitar hutan, yang meliputi usaha hulu, usaha tani, agroindustri , pemasaran dan jasa penunjang (Anonim, 2006).

Proses pemberdayaan (empowerment) petani ditujukan untuk membantu petani memperoleh daya (kuasa) dalam mengambil keputusan dan menentukan tindakan yang akan dilakukan diantara alternatif -alternatif yang ada. Pemberdayaan petani pada intinya membahas cara petani selaku individu, kelompok, ataupun komunitas berusaha mengontrol kehidupan dan mengusahakan untuk membentuk masa depan sesuai dengan keinginan. Prinsip ini pada intinya mendorong petani untuk menentukan sendiri kegiatan yang harus dilakukan terkait dengan upaya mengatasi permasalahan yang dihadapi, sehingga petani mempunyai kesadaran dan kekuasaan penuh untuk membentuk masa depannya.

Pemberdayaan petani merupakan the missing ingredient dalam mewujudkan partisipasi petani yang aktif dan kreatif (Nurmayasari et al. 2020). Secara sederhana, pemberdayaan petani mengacu kepada kemampuan petani untuk mendapatkan dan memanfaatkan akses ke dan kontrol atas sumber daya yang penting.

\section{CSR dalam Kerangka Pergeseran Paradigma Pembangunan}

CSR berorientasi pada planet (konservasi), people (komunitas), dan profit (keuntungan perusahaan) yang dilaksanakan oleh perusahaan. Orientasi pada planet difokuskan untuk menciptakan lingkungan ekologis yang berkelanjutan (environmental sustainability). Memberdayakan komunitas dan meningkatkan partisipasi multipihak (stakeholders participation) menjadikan orientasi CSR kepada masyarakat (people). Kedua orientasi tersebut menjadi bagian tak terpisahkan dari strategi perusahaan untuk memperoleh keuntungan, lazimnya suatu private sector (Mutolib, Sumaryo dan Viantimala, 2013; Irawati dan Rangga, 2019).

Sinergitas dari ketiga orientasi tersebut dimanifestasikan sebagai upaya perusahaan untuk menginternalisasikan faktor-faktor luar ke dalam kebijakan perusahaan (the internalization of externalities) dalam kerangka CSR. Oleh karena itu programprogram CSR adalah salah satu aksi dalam kerangka kebijakan perusahaan yang selalu mempertimbangkan berbagai faktor luar 
(faktor-faktor di luar perusahaan dan relevan dengan perusahaan) baik faktor sosial (masyarakat) maupun faktor sumberdaya alam yang perlu dikonservasi. Mempertimbangkan berbagai faktor luar tersebut dipahami oleh perusahaan dengan memfokusksn pada struktur sosial, kultur (pola-pola kebudayaan), dan pola-pola adaptasi ekologi dalam rangka merespon perubahan sumberdaya alam yang cenderung semakin terdegradasi.

\section{METODE PENELITIAN}

\section{Kerangka Pikir}

Pemberdayaan merupakan suatu proses untuk mengupayakan agar manusia menjadi berdaya, yakni meningkat pengetahuannya, ketrampilannya, dan mampu mengatasi problema yang dihadapi. Pemberdayaan seringkali dikenal sebagai penyuluhan atau pendampingan ataupun pembimbingan, dengan tujuan utama merubah pengetahuan, sikap, dan ketrampilannya sehingga akhirnya berubah perilakunya sesuai dengan yang diharapkan.

CSR merupakan suatu proses pembelajaran yang partisipatif yang diharapkan mampu meningkatkan keberdayaan masyarakat (Elkington. Dalam Nasdian, 2014:229), dengan demikian konsep Elkington ini mirip dengan konsep penyuluhan yang diajukan Rogers. M Rogers (1995) dan beberapa ahli penyuluhan, menjelaskan bahwa penyuluhan adalah proses pembelajaran/non formal education untuk mengubah perilaku masyarakat agar menjadi lebih baik melalui perubahan pengetahuan, sikap, dan keterampilan. Dengan demikian, pemberdayaan pada akhirnya akan mengubah pengetahuan, ketrampilan, sehingga peserta memiliki keberdayaan yakni pengetahuan dan ketrampilan yang tinggi serta perilaku yang mampu mengatasi problema yang dihadapi.

Dalam program pemberdayaan oleh CSR ini, Pertamina melalui aktivitas petugasnya memberikan bantuan sarana prasarana pertanian (fasilitator), mendorong berusaha tani (motivator), dan mendidik cara usaha tani yang baik (edukator). Dampak dari pemberdayaan ini dapat berupa meningkatnya pengetahuan, ketrampilan, maupun kemampuan mengatasi problem yang dihadapi. Teori Tindakan Berencana (Planned Behaviour) dari Azjen \& Fishbein (dalam Hariadi. 2011) menjelaskan bahwa adanya stimulus akan memberikan respon atau tanggapan, dalam program CSR ini stimulus berupa adanya fasilitasi dan berbagai kegiatan dari petugas CSR. Dengan demikian, stimulus dari petugas CSR yang berperan sebagai fasilitator, edukator, dan motivator ini akan memberikan dampak pada peserta yakni adanya tanggapan, tanggapan dapat berupa tanggapan yang baik/positif ataupun tanggapan yang tidak baik/negatif, bahkan mungkin beragam tanggapan dari yang sangat baik sampai dengan yang sangat tidak baik.

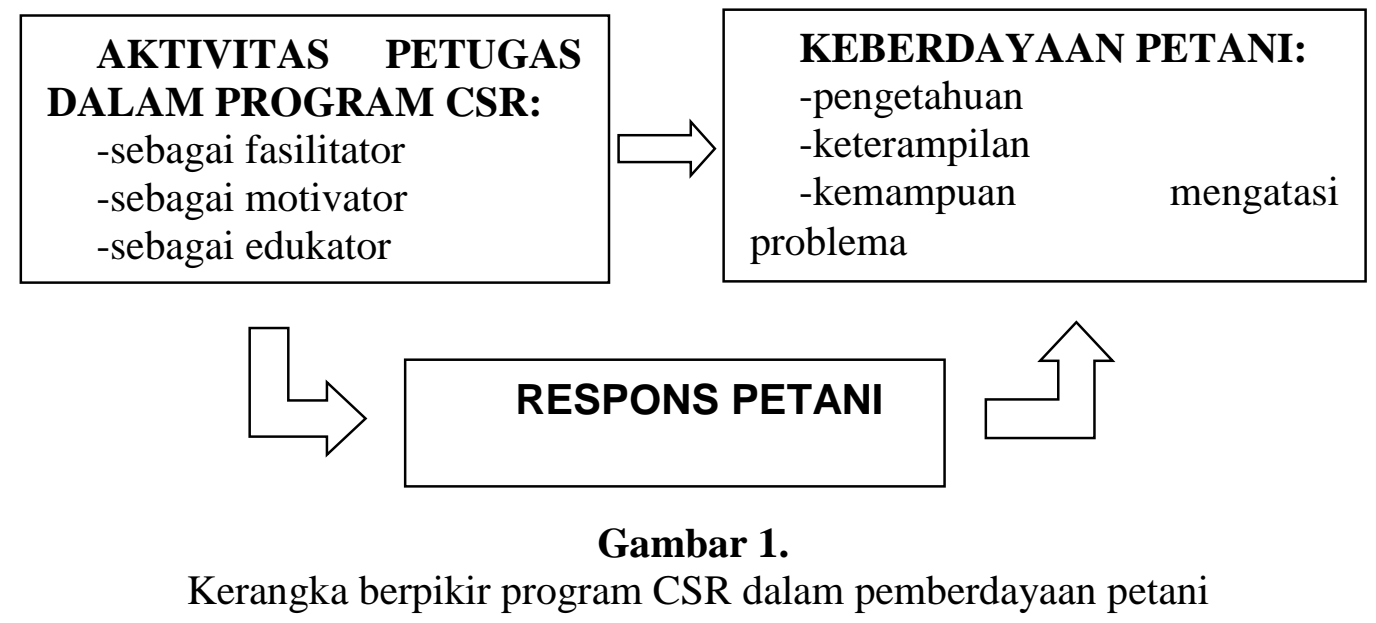


Pemberdayaan

menghasilkan perubahan pengetahuan, ketrampilan, dan kemampuan mengatasi problema usaha. Petugas dalam proses pemberdayaan masyarakat dapat berperan sebagai fasilitator, motivator, edukator. Dalam hal ini peserta (petani) tentu saja dapat memberikan berbagai respons kepada petugas. Respons yang baik atau positif dari petani cenderung akan meningkatkan antusiasme petani untuk mengikuti CSR, sehingga akan berdampak dapat meningkatkan pengetahuan, ketrampilan, dan kemampuannya mengatasi problema yang dihadapi. Namun demikian Azjen \& Fishbein juga menjelaskan, bahwa bisa terjadi respons atau tanggapan yang positif tetapi tidak meningkatkan antusiasme mengikuti CSR karena faktor subjective norm (lingkungan terdekat atau keluarga yang tidak mendukung) ataupun control behaviour (mudah tidaknya melakukan misalnya petani sulit hadir dalam pertemuan kelompok karena berbarengan dengan kegiatan lain). Sebaliknya, kata Azjen \& Fishbein, bahwa bisa terjadi respon/ tanggapan yang negatif tetapi justru aktif mengikuti kegiatan kelompok CSR dikarenakan ada unsur "paksaan" dari pejabat misalnya pamong desa.

\section{Metode Pengambilan Sampel}

Penelitian ini termasuk penelitian survei dengan pendekatan kuantitatif yang didukung kualitatif. Subyek penelitian terdiri dari Kelompok Binaan CSR , pengelola CSR, tokoh masyarakat dan perangkat Desa Argomulyo , Kecamatan Sedayu, Kabupaten Bantul DIY. Program CSR PT Pertamina (pesero) Terminal Bahan Bakar Minyak (TBBM) Rewulu Yogyakarta dalam memberdayakan petani di sekitar perusahaan.

Lokasi Penelitian dilaksanakan di pedukuhan di sekitar daerah operasi Pertamina Terminal Bahan Bakar Minyak (TBBM) Rewulu Yogyakarta yakni di Pedukuhan Watu dan pedukuhan Plawonan Desa Argamulyo Kecamatan Sedayu Kabupaten Bantul DIY.

\section{Teknik Pengumpulan Data}

Observasi dilakukan untuk memperoleh gambaran kondisi petani dan usaha taninya dalam pelaksanaan program CSR di sekitar TBBM Rewulu. Wawancara secara mendalam dengan Ketua Kelompok Binaan CSR TBBM Rewulu, pihak pengelola program CSR, tokoh masyarakat, perangkat desa di sekitar perusahaan tentang program CSR dan permasalahan yang dihadapi.

Kuesioner diberikan kepada petani anggota kelompok binaan terkait dengan pelaksanaan program CSR yang meliputi: aktivitas petugas CSR dalam memfasilitasi, memotivasi dan mengedukasi, keberdayaan petani, tanggapan petani dan partisipasi petani, manfaat yang dirasakan dan masalah yang dihadapi serta analisis usaha tani. Dokumentasi untuk memperoleh data-data sekunder baik monografi desa, dokumen pengelolaan CSR, dan foto-foto yang diperlukan.

\section{Jenis dan Sumber Data}

Jenis dan sumber data dalam kajian ini meliputi data primer dan data sekunder. Data primer berasal dari responden dan informan. Responden terdiri dari anggota kelompok, ketua kelompok binaan CSR TBBM Rewulu, tokoh masyarakat, perangkat desa, dan pengelola progam CSR. Data sekunder diperoleh dari pustaka, dokumen-dokumen yang ada di dusun, desa dan Pengelola dana CSR.

\section{Penentuan dan Jumlah Sampel}

Populasi adalah semua petani anggota kelompok binaan program CSR TBBM Rewulu (petani yang mengikuti program CSR) di Desa Argomulyo. Sifat populasi relatif homogen ditinjau dari luas lahan garapan pertanian. Metode pengambilan sampel menggunakan teknik Simple Random Sampling. Jumlah sampel yang diambil dalam penelitian ini sebanyak 22 petani. 


\section{Analisis Data}

Analisis data dalam penelitian ini dilakukan dengan metode statistik deskriptif yang berbentuk tabel-tabel frekuensi dan statistik inferens dalam bentuk korelasi tata jenjang (korelasi Spearman). Data kualitatif dan kuantitatif yang terkumpul ditabulasi, diklasifikasi, diolah, dan dianalisis kemudian diinterpretasikan untuk menentukan kesimpulan dan rekomendasi serta tindak lanjut bagi keberlanjutan program CSR bagi peningkatan kesejahteraan dan kemandirian masyarakat. Pengujian hipotesis dilakukan dengan metode statistik inferens melalui uji statistik non parametrik.

\section{HASIL DAN PEMBAHASAN}

Berbagai aktivitas petugas CSR mendapat tanggapan dari petani. Namun demikian, di era digitalisasi ini para petugas belum banyak menggunakan media sosial untuk meningkatkan keberdayaan petani. Penelitian Puslitbang PPI Kominfo juga mendapatkan bahwa golongan petani, buruh, nelayan belum banyak yang memanfaatkan karena tingkat literasi TIK masyarakat golongan ini masih sangat rendah ( Kominfo cit Masyhur. 2016). Namun demikian koneksi komunikasi umumnya sudah menggunakan WA ataupun SMS.

Tabel 1.

Pendapat responden tentang aktivitas petugas CSR memberi fasilitas peralatan sesuai kebutuhan

\begin{tabular}{llrr}
\hline No & \multicolumn{1}{c}{ Pendapat } & Frekuensi & $\begin{array}{c}\text { Persentase } \\
(\%)\end{array}$ \\
\hline 1. & Sangat tidak sesuai & 0 & 0 \\
2. & Tidak sesuai & 0 & 0 \\
3. Kurang sesuai & 6 & 27,27 \\
4. & Sesuai & 15 & 68,18 \\
5. & Sangat sesuai & 1 & 4,55 \\
\hline & Jumlah & 22 & 100,00 \\
\hline
\end{tabular}

Sumber: Widiputranti, 2016

\section{Respons Petani terhadap CSR}

Respons petani terhadap program CSR ini ditinjau dari program CSR dalam meningkatkan produksi dan pendapatan petani. Pada analisis ini juga akan diketahui tanggapan petani terhadap program CSR merepotkan atau tidak karena menambah beban tenaga kerja. Tanggapan petani tersebut disajikan pada berikut ini.

\section{Tabel 2.}

Pendapat responden tentang aktivitas petugas CSR memotivasi ikut sosialisasi dan memberikan pelatihan usaha pertanian

\begin{tabular}{llrrrr}
\hline \multirow{2}{*}{ No. } & Pendapat & \multicolumn{2}{c}{$\begin{array}{c}\text { CSR } \\
\text { memotivasi } \\
\text { ikut sosialisasi }\end{array}$} & \multicolumn{3}{c}{$\begin{array}{c}\text { CSR pelatihan } \\
\text { pertanian }\end{array}$} \\
\cline { 3 - 7 } & & $\begin{array}{c}\text { Freku- } \\
\text { ensi }\end{array}$ & $(\%)$ & $\begin{array}{c}\text { Freku- } \\
\text { ensi }\end{array}$ & $(\%)$ \\
\hline 1. & Tidak pernah & 0 & 0 & 0 & 0 \\
2. $\quad$ Jarang & 0 & 0 & 0 & 0 \\
3. & Kadang-kadang & 3 & 13,64 & 3 & 13,64 \\
4. & Sering & 15 & 68,18 & 15 & 68,18 \\
5. $\quad$ Sangat sering & 4 & 18,18 & 4 & 18,18 \\
\hline Jumlah & 22 & 100 & 22 & 100 \\
\hline
\end{tabular}

Sumber: Widiputranti, 2016

\section{Tabel 3.}

Respons petani terhadap dampak program CSR terhadap peningkatan produksi pertanian, penongkatan pendapatan petani dan menambah beban tenaga kerja

\begin{tabular}{lrrr}
\hline \multirow{2}{*}{ Respons } & \multicolumn{4}{c}{ Persentase (\%) } \\
\cline { 2 - 4 } & $\begin{array}{c}\text { Peningkatan } \\
\text { produksi } \\
\text { pertanian }\end{array}$ & $\begin{array}{c}\text { Peningkatan } \\
\text { pendapatan } \\
\text { petani }\end{array}$ & $\begin{array}{c}\text { Penambahan } \\
\text { beban tenaga } \\
\text { kerja }\end{array}$ \\
\hline Sangat setuju & 54,55 & 13,64 & 0 \\
Setuju & 40,91 & 40,91 & 4,55 \\
Ragu-ragu & 4,55 & 45,45 & 13,64 \\
Tidak setuju & 0 & 0 & 40,91 \\
Sangat tidak & 0 & 0 & 40,91 \\
setuju & & & \\
\hline Jumlah & 100,00 & 100,00 & 100,00 \\
\hline
\end{tabular}

Sumber: Widiputranti, 2016

Lebih dari 50\% (sebagian besar) petani yang sangat setuju bahwa program CSR membantu meningkatkan produksi pertanian. Berikutnya sebesar $40,91 \%$ dari total responden setuju jika program tersebut meningkatkan produksi pertanian. Hasil terendah yaitu sebesar $4,55 \%$ petani masih ragu-ragu program tersebut betul-betul dapat meningkatkan produksi pertanian.

Sebaliknya, data pada Tabel 3. menunjukkan bahwa sebagian besar petani yaitu $45,45 \%$ orang masih ragu-ragu terhadap manfaat program CSR dalam meningkatkan pendapatan petani. 
Selanjutnya, 40,91\% petani menunjukkan sikap setuju terhadap peningkatan pendapatan yang merupakan hasil dari program CSR. Hanya $13,64 \%$ petani yang sangat setuju terhadap peningkatan pendapatan tersebut.

Respons sebagian besar petani positif terhadap program CSR. Terdapat masingmasing 40,91\% petani yang sangat tidak setuju bahwa program tersebut merepotkan karena menambah beban tenaga kerja. Persentase jumlah petani yang masih raguragu program tersebut merepotkan adalah $13,64 \%$. Sebagian kecil petani yaitu $4,55 \%$ orang setuju jika program tersebut dianggap merepotkan.

\section{Keberdayaan Petani}

Keberdayaan petani dapat ditinjau dari peningkatan pengetahuan petani, keterampilan petani dan kemampuan petani mengatasi problema. Hal ini dapat diuraikan sebagai berikut:

\section{Pengetahuan Petani}

Keberdayaan petani ditinjau dari peningkatan pengetahuan dapat dilihat dari pengetahuan tentang cara berproduksi bertambah,pengetahuan cara penjualan bertambah, dan cara pengembangan usaha bertambah.

Tabel 4.

Pendapat responden tentang pengetahuan cara berproduksi bertambah

\begin{tabular}{|c|c|c|c|}
\hline \multirow[b]{2}{*}{ Pendapat } & \multicolumn{3}{|c|}{ Persentase $(\%)$} \\
\hline & $\begin{array}{l}\text { Peningkatan } \\
\text { pengetahuan cara } \\
\text { berproduksi }\end{array}$ & $\begin{array}{l}\text { Peningkatan } \\
\text { pengetahuan } \\
\text { penjualan }\end{array}$ & $\begin{array}{l}\text { Penigkatan } \\
\text { pengetahuan } \\
\text { pengembang- } \\
\text { an usaha }\end{array}$ \\
\hline Tidak tambah & 0 & 31,82 & 13,64 \\
\hline Tambah sedikit & 4,55 & 31,82 & 22,73 \\
\hline $\begin{array}{l}\text { Tambah } \\
\text { banyak }\end{array}$ & 40,91 & 27,27 & 59,09 \\
\hline $\begin{array}{l}\text { Tambah sangat } \\
\text { banyak }\end{array}$ & 54,55 & 9,09 & 4,55 \\
\hline Jumlah & 100,00 & 100,00 & 100,00 \\
\hline
\end{tabular}

Sumber: Widiputranti, 2016

Berbagai upaya pemberdayaan masyarakat tani oleh program CSR telah membuahkan hasil. Data pada Tabel 4 menunjukkan bahwa tidak ada petani yang tidak bertambah pengetahuannya dalam cara berpodruksi. Selain itu, sebagian besar petani yaitu 54,55\% mengaku bahwa pengetahuannya bertambah sangat banyak. Kemudian, diikuti oleh bertambahnya banyak pengetahuan oleh $40,91 \%$ responden dan bertambahnya sedikit pengetahuan oleh $4,55 \%$ responden.

Sebagian besar $(31,82 \%)$ responden, merasa pengetahuannya tentang cara penjualan tidak bertambah. Jumlah responden yang sama juga mengaku bahwa pengetahuannya hanya bertambah sedikit. Hasil ini berkaitan dengan fasilitas pemasaran. Kurangnya fasilitas pemasaran yang diberikan oleh petugas CSR berpengaruh terhadap penambahan pengetahuan para petani. Akan tetapi, terdapat $27,27 \%$ responden yang bertambah banyak pengetahuannya bahkan $9,09 \%$ lainnya bertambah sangat banyak.

Terlepas dari sedikitnya jumlah responden yang merasa bahwa pengetahuannya dalam kegiatan pemasaran banyak bertambah, Tabel 4 menyajikan data terkait penambahan pengetahuan responden tentang cara pengembangan usaha dengan hasil yang berbeda. Lebih dari $50 \%$ responden, lebih tepatnya $59,09 \%$ orang mengalami banyak penambahan pengetahuan untuk pengembangan usahanya dan nilai terendah yaitu $4,55 \%$ orang merasakan penambahan yang sangat banyak.

Apabila diamati lebih mendetail, jumlah responden yang merasa jika pengetahuannya tidak bertambah hingga ke pengetahuannya bertambah banyak mengalami kenaikan jumlah responden dengan nilai berutrut-turut sebesar 13,64\%; 22,73\%; dan 59,09\% orang. Kenaikan tersebut mencapai titik maksimal pada jumlah responden yang bertambah banyak pengetahuannya. Kemudian, jumlah responden menurun lagi pada tingkat pengetahuan yang bertambah banyak. Hal ini berarti program CSR telah berhasil mengembangkan pengetahuan petani yang tadinya tidak tahu atau sedikit tahu menjadi tahu atau lebih banyak tahu. Apabila terus 
dikembangkan, jumlah responden yang menjadi banyak tahu akan semakin meningkat dari $4,55 \%$.

\section{Keterampilan Petani}

Keberdayaan petani ditinjau dari peningkatan keterampilan dapat dilihat dari bertambahnya keterampilan cara berproduksi,cara pengolahan hasil,dan cara pengembangan usaha.

Tabel 5.

Pendapat responden tentang keterampilan cara berproduksi bertambah

\begin{tabular}{|c|c|c|c|}
\hline \multirow[b]{2}{*}{ Pendapat } & \multicolumn{3}{|c|}{ Persentase (\%) } \\
\hline & $\begin{array}{c}\text { Peningkatan } \\
\text { keterampilan } \\
\text { cara } \\
\text { berproduksi }\end{array}$ & $\begin{array}{l}\text { Peningkatan } \\
\text { keterampilan } \\
\text { pengolahan } \\
\text { hasil }\end{array}$ & $\begin{array}{c}\text { Peningkatan } \\
\text { keterampilan } \\
\text { pengembangan } \\
\text { usaha }\end{array}$ \\
\hline Tidak tambah & 0 & 9,09 & 4,55 \\
\hline Tambah sedikit & 4,55 & 31,82 & 31,82 \\
\hline Tambah banyak & 77,27 & 50,00 & 63,64 \\
\hline $\begin{array}{l}\text { Tambah sangat } \\
\text { banyak }\end{array}$ & 18,18 & 9,09 & 0 \\
\hline Jumlah & 100,00 & 100,00 & 100,00 \\
\hline
\end{tabular}

Sumber: Widiputranti, 2016

Dari Tabel 5 dapat diketahui bahwa $77,27 \%$ atau sebagian besar petani berpendapat bahwa keterampilannya banyak bertambah dengan bantuan program CSR. Sisanya yaitu $18,18 \%$ petani merasa keterampilannya bertambah sangat banyak dan $4,55 \%$ bertambah sedikit. Tidak semua petani yang pengetahuannya sangat banyak bertambah juga meningkat keterampilannya. Dari $54,55 \%$ petani yang bertambah sangat banyak pengetahuannya dalam hal produksi hanya $18,18 \%$ yang keterampilannya juga bertambah sangat banyak. Jadi, untuk meningkatkan keterampilan pada tingkat yang sangat tinggi dibutuhkan suatu proses.

Sebagian besar $(50 \%)$ responden menyatakan keterampilan cara pengolahan hasil pertanian bertambah banyak. Terdapat $31,82 \%$ orang yang berpendapat bahwa keterampilannya bertambah sedikit. Sementara itu, petani dengan keterampilan yang bertambah sangat banyak maupun tidak bertambah sama sekali masing-masing ada $9,09 \%$ orang. Seperti keterampilan yang lain, keterampilan pengembangan usaha dari $63,64 \%$ petani sangat banyak meningkat.
Peningkatan keterampilan selanjutnya dirasakan oleh $31,82 \%$ orang yang mengaku bahwa keterampilan yang dimiliki telah sedikit mengalami peningkatan. Sisanya sebanyak $4,55 \%$ orang lainnya mengatakan bahwa keterampilannya tidak bertambah meskipun telah mendapatkan fasilitas dari program CSR.

\section{Kemampuan Petani Mengatasi Problema}

Keberdayaan petani ditinjau dari kemampuan petani mengatasi problema dapat dilihat dari meningkatnya kemampuan mengatasi cara berproduksi, kemampuan mengatasi cara pengolahan hasil, dan kemampuan mengatasi cara mengembangkan usaha.

\section{Tabel 6.}

Pendapat responden tentang kemampuan mengatasi cara berproduksi bertambah

\begin{tabular}{lrrr}
\hline \multirow{2}{*}{ Pendapat } & \multicolumn{3}{c}{ Persentase (\%) } \\
\cline { 2 - 4 } & $\begin{array}{c}\text { Mengatasi } \\
\text { problema } \\
\text { berproduksi }\end{array}$ & $\begin{array}{c}\text { Mengatasi } \\
\text { problema } \\
\text { pengolahan } \\
\text { hasil }\end{array}$ & $\begin{array}{c}\text { Mengatasi } \\
\text { problema } \\
\text { pengembangan } \\
\text { usaha }\end{array}$ \\
\hline Tidak tambah & 9,09 & 4,55 & 9,09 \\
Tambah sedikit & 13,64 & 54,55 & 54,55 \\
Tambah banyak & 68,18 & 40,91 & 36,36 \\
Tambah sangat & 9,09 & & 0 \\
banyak & 100,00 & 100,00 & 100,00 \\
\hline Jumlah & & & \\
\hline
\end{tabular}

Sumber: Widiputranti, 2016

Hasil tertinggi didapat pada bertambahnya kemampuan $68,18 \%$ petani dalam mengatasi masalah cara berproduksi. Sebanyak $13,64 \%$ petani memiliki pendapat bahwa program CSR meningkatkan sedikit kemampuan untuk menyelesaikan masalah. Hanya masing-masing $9,09 \%$ orang saja yang kemampuannya sangat banyak bertambah maupun sama sekali tidak bertambah

Dalam hal kemampuan mengatasi masalah cara pengolahan hasil pertanian, mayoritas petani yaitu sebanyak 54,55\% orang mengalami sedikit peningkatan kemampuan. Selain itu, terdapat 40,91\% petani yang mengaku bahwa kemampuannya banyak bertambah. Akan tetapi, masih ada $4,55 \%$ lainnya yang tidak mengalami 
peningkatan kemampuan untuk mengatasi permasalahan terkait pengolahan hasil.

Hasil tertinggi hingga terendah mengenai peningkatan kemampuan petani dalam mengatasi masalah pada pengembangan usaha sama seperti kemampuan mengatasi masalah pengolahan hasil pada Tabel 6. Sebagian besar $(54,55 \%)$ petani juga mengalami sedikit peningkatan kemampuan mengatasi cara pengembangan usaha. Terdapat $36,36 \%$ responden dengan kemampuan yang banyak mengalami peningkatan. Kemudian 9,09\% petani yang tidak bertambah kemampuannya. Selain itu, tidak ada petani yang kemampuannya sangat banyak meningkat.

\section{Dampak Program CSR Terhadap Pemberdayaan Petani}

Program CSR Pertamina TBBM Rewulu dalam pemberdayaan petani dapat dianalisis dari aktivitas petugas CSR sebagai fasilitator, motivator dan edukator. Dampak dari aktivitas petugas CSR tersebut adalah meningkatnya keberdayaan petani berupa meningkatnya pengetahuan, keterampilan, dan kemampuan mengatasi problema. Program CSR Pertamina TBBM Rewulu dalam pemberdayaan petani dapat ditunjukkan dari hasil analisis hubungan antara aktivitas petugas CSR (sebagai fasilitator, motivator dan edukator) dengan respons petani dan hubungan antara respons petani dengan tingkat keberdayaan. Hasil perhitungan Korelasi Spearman tentang hubungan antar variabel tersebut dapat dilihat pada tabel berikut:

Tabel 7.

Korelasi Spearman antar variabel

\begin{tabular}{|c|c|c|c|}
\hline $\begin{array}{l}\text { Korela-si antar } \\
\text { variabel }\end{array}$ & $\begin{array}{c}\text { Koefisien } \\
\text { Korelasi } \\
(\mathrm{r})\end{array}$ & $\begin{array}{c}\text { Tingkat } \\
\text { kesalahan }\end{array}$ & $\begin{array}{c}\text { Toleransi } \\
\text { kesalahan } \\
(\alpha)\end{array}$ \\
\hline $\begin{array}{l}\text { Aktivi-tas } \\
\text { petugas CSR } \\
\text { dengan respons } \\
\text { petani }\end{array}$ & 0,545 & $0,9 \%$ & $1 \%$ \\
\hline $\begin{array}{l}\text { Respons petani } \\
\text { dengan tingkat } \\
\text { keberdayaan } \\
\text { petani }\end{array}$ & 0,475 & $2,6 \%$ & $5 \%$ \\
\hline
\end{tabular}

Sumber: Widiputranti, 2016
Ada hubungan positif yang signifikan (dengan tingkat kesalahan 1\%) antara aktivitas petugas CSR dengan respons petani. Artinya semakin aktif petugas CSR sebagai fasilitator, motivator dan edukator maka respons petani semakin baik.. Dengan demikian pada tingkat kepercayaan 99,1\%, hipotesis 1: semakin aktif petugas CSR (memfasilitasi, memotivasi dan mengedukasi) maka respons petani semakin baik dapat diterima.

Ada hubungan positif yang signifikan (dengan tingkat kesalahan 2,6\%) antara respons petani dengan tingkat keberdayaan petani. Artinya semakin baik respons petani maka keberdayaan petani semakin meningkat. Dengan demikian pada tingkat kepercayaan $97,4 \%$, hipotesis 2: semakin baik respons petani terhadap petugas CSR maka keberdayaan petani semakin meningkat dapat diterima.

\section{SIMPULAN}

Aktivitas petugas CSR yang meningkat dalam memotivasi, memfasilitasi, mengedukasi para petani dan masyarakat pedesaan telah berhasil meningkatkan respons petani dalam kegiatan CSR, sehingga para petani kemudian aktif mengikuti kegiatan yang dilakukan oleh petugas CSR. Dengan demikian petugas CSR berhasil meningkatkan keberdayaan petani, yakni petani mampu meningkatkan pengetahuan, ketrampilan, dan kemampuan mengatasi problema yang dihadapi. Untuk koneksi komunikasi umumnya sudah menggunakan WA ataupun SMS, namun demikian penggunaan media sosial untuk pemberdayaan masyarakat masih lemah, yang diantaranya karena tingkat literasi TIK (Teknologi Informasi Komunikasi) yang masih lemah.

\section{DAFTAR PUSTAKA}

Anonim. 2006. Undang Undang Nomor 16 Tahun 2006 tentang Sistem Penyuluhan Pertanian, Perikanan dan 
Kehutanan. Pusat Pengembangan Penyuluhan Pertanian Badan Pengembangan SDM Pertanian Departemen Pertanian.

Hadi, Sutrisno. 1984. Metodologi Research. Yayasan Penerbitan Fakultas Psikologi UGM.Yogyakarta.

Hariadi, Sunarru Samsi. 2011. Dinamika Kelompok. Pascasarjana UGM. Yogyakarta.

Hasanuddin, T., Viantimala, B., dan Fitriyani, A. (2019). Kinerja Penyuluh Pertanian Lapangan, Kepuasan Petani, dan Produktivitas Usahatani Jagung di Kecamatan Natar, Kabupaten Lampung Selatan. Suluh Pembangunan : Journal of Extension and Development. 1(2): 134-141

Irawati, D.A. dan Rangga, K.K. 2019. Konsep Tanggung Jawab Sosial Perguruan Tinggi untuk Pemberdayaan Masyarakat di Sektor Peternakan. Suluh Pembangunan: Journal of Extension and Development, 1(2). 122133

Masyhur, Firdaus. 2016. Model Pengembangan Literasi TIK Masyarakat Tani dan Nelayan. Jurnal Pekomnas. Vol1. No.1. April 2016.

Mosher, A.T. 1984. Menggerakkan dan Membangun Pertanian. Jakarta. CV Yasaguna.

Mutolib, A., Sumaryo., dan Viantimala, B. (2013). Kebutuhan Masyarakat Sekitar Perusahaan Untuk Program Corporate Social Responsibility Pt PLN (Persero) Sektor Pembangkitan Tarahan: Kasus Di Desa Rangai Tri Tunggal Kecamatan Katibung Kabupaten Lampung Selatan. Jurnal Ilmu-Ilmu Agribisnis, 1(2): 126-133.
Nasdian, Tonny, Fredian. 2014. Pengembangan Masyarakat. Jakarta, Yayasan Pustaka Obor Indonesia.

Nurmayasari, I., Viantimala, B., Gultom, D.T., Yanfika, H. dan Mutolib, A. (2020). Partisipasi dan Kepuasan Petani Terhadap Kinerja Penyuluh Pertanian di Kecamatan Palas Kabupaten Lampung Selatan. MIMBAR AGRIBISNIS: Jurnal Pemikiran Masyarakat Ilmiah Berwawasan Agribisnis. 6(1): 448459.

Rogers, Everet M. 1995. Diffusion of Innovations. New york. The Free Press.

Widiputranti, Christine Sri. 2016. Program Corporate Social Responsibility Perusahaan P T Pertamina Terminal Bahan Bakar Minyak Rewulu Dalam Pemberdayaan Petani Di Desa Argomulyo Kecamatan Sedayu Kabupaten Bantul Daerah Istimewa Yogyakarta. Laporan Penelitian. Sekolah Tinggi Pembangunan Masyarakat Desa "APMD". Yogyakarta. Unpublish.

Widiputranti, Christine Sri. 2007. Pemberdayaan Petani Agar Mampu Mengembangkan Agribisnis, dalam Jurnal Ilmu-ilmu Pertanian, volume 3 nomor 1 Juli 2007. ISSN 1858-1226. STTP Magelang.

Yanfika, H. Mutolib, A. Gultom, D.T. Rivandi, D.R. 2020. Pemberdayaan Kelompok Wanita Tani Melalui Budidaya Perikanan Teknik Bioflok Di Kecamatan Adiluwih Kabupaten Pringsewu. Jurnal ABDINUS: Jurnal Pengabdian Nusantara, 3(2): 215-225. 